\title{
ANALISIS PENGARUH RASIO PROFITABILITAS TERHADAP HARGA SAHAM PADA PERUSAHAAN REAL ESTATE DAN PROPERTY YANG TERDAFTAR DI BURSA EFEK INDONESIA TAHUN 2012-2014
}

\author{
Sari Rolensa Tejaningtyas \\ Program Studi Akuntansi Universitas Mercu Buana Yogyakarta \\ Email: sarirolensa@gmail.com
}

\begin{abstract}
Abstrak
Perdagangan surat berharga merupakan cara untuk menarik dana masyarakat dalam hal ini investor untuk mengembangkan perekonomian dimana dana tersebut adalah modal yang dibutuhkan perusahaan untuk memperluas usahanya. Dengan dijualnya saham pasar modal berarti masyarakat diberi kesempatan untuk memiliki dan mendapatkan keuntungan. Populasi dalam penelitian ini adalah perusahaan Real Estate and Property yang terdaftar di Bursa Efek Indonesia pada tahun 2012 hingga tahun 2014. Sampel adalah bagian dari jumlah dan karakteristik yang dimiliki oleh populasi tersebut yang ingin diteliti (Sugiyono, 2010). Purposive sampling adalah pengambilan sampel dari populasi secara sengaja berdasarkan penilaian atau kriteria tertentu. Alat analisis yang digunakan adalah regresi linier berganda. Hasil penelitian menunjukkan bahwa Variabel EPS berpengaruhterhadap harga saham pada perusahaan Perusahaan Real Estate dan Property di Bursa Efek Indonesia. Variabel DPS berpengaruh terhadap harga saham pada Perusahaan Real estate dan Property di Bursa Efek Indonesia. Variabel ROI tidak berpengaruh terhadap harga saham pada Perusahaan Real Estate dan Propertydi Bursa Efek Indoinesia.
\end{abstract}

Kata kunci : EPS, DPS, ROI dan harga saham

\section{ANALYSIS OF EFFECT OF PROFITABILITY RATIOS ON STOCK PRICES ON REAL ESTATE AND PROPERTY COMPANIES LISTED IN INDONESIA STOCK EXCHANGE 2012 - 2014}

\author{
Sari Rolensa Tejaningtyas \\ Program Studi Akuntansi Universitas Mercu Buana Yogyakarta \\ Email: sarirolensa@gmail.com
}

\begin{abstract}
Securities trading is the way to attract public funds in this case the investor to develop the economy in which the fund is capital that the company needs to expand its business. By selling shares of capital markets means that the public is given the opportunity to own and benefit. The population in this study is the Real Estate and property companies listed on the Indonesia Stock Exchange in 2012 to 2014. The sample is part of the number and characteristics possessed by the population who want to learn (Sugiyono, 2010). Purposive sampling is a sampling of the population deliberately based on an assessment or specific criteria. The analytical tool used is multiple linear regression. The results showed that the variables EPS effect on Company's share price on the company's Real Estate and Property in the Exchange Indonesia. Variabel DPS affect stock prices in Corporate Real Estate and Property in the Exchange Indonesia. Variabel ROI no effect to the company's stock price.
\end{abstract}

Keywords: EPS, DPS, ROI and stock prices 


\section{PENDAHULUAN}

Perdagangan surat berharga merupakan cara untuk menarik dana masyarakat dalam hal ini investor untuk mengembangkan perekonomian dimana dana tersebut adalah modal yang dibutuhkan perusahaan untuk memperluas usahanya. Dengan dijualnya saham pasar modal berarti masyarakat diberi kesempatan untuk memiliki dan mendapatkan keuntungan. Dengan kata lain pasar modal dapat membantu pendapatan masyakarat. Motif dari perusahaan yang menjual sahamnya untuk memperoleh dana yang akan digunakan dalam pengembangan usahanya dan bagi pemodal adalah untuk mendapatkan penghasilan dari modalnya (Arista danAstohar, 2012).

Harga saham merupakan faktor yang sangat penting dan harus diperhatikan oleh investor dalam melakukan investasi karena harga saham menunjukkan prestasi emiten, pergerakan harga saham searah dengan kinerja emiten. Apabila emiten mempunyai prestasi yang semakin baik maka keuntungan yang dapat dihasilkan dari operasi usaha semakin besar. Pada kondisi yang demikian, harga saham emiten yang bersangkutan cenderung naik (Priantinah, 2013)

Harga saham juga menunjukkan nilai suatu perusahaan. Nilai saham merupakan indeks yang tepat untuk efektifitas perusahaan. Sehingga sering kali dikatakan memaksimumkan nilai perusahaan juga berarti memaksimumkan kekayaan pemegang saham. Dengan semakin tinggi harga saham, maka semakin tinggi pula nilai perusahaan tersebut dan sebaliknya. Oleh karena itu, setiap perusahaan yang menerbitkan saham sangat memperhatikan harga sahamnya. Harga yang terlalu rendah sering diartikan bahwa kinerja perusahaan kurang baik. Namun bila harga saham terlalu tinggi mengurangi kemampuan investor untuk membeli sehingga menimbulkan harga saham sulit untuk meningkat lagi. Dengan perubahan posisi keuangan hal ini akan mempengaruhi harga saham perusahaan. Laporan keuangan dirancang untuk membatu para pemakai laporan untuk mengidentifikasi hubungan variabel-variabel dari laporan keuangan (Arista danAstohar, 2012).

\section{RUMUSAN MASALAH}

Berdasarkan latar belakang di atas, rumusan masalah penelitian ini adalah :

1. Apakah Earning Per Share berpengaruh terhadap harga saham pada Perusahaan Real Estate dan Property?

2. Apakah Dividend Per Share berpengaruh terhadap harga 
saham pada Perusahaan Real Estate dan Property?

3. Apakah Return on Investment berpengaruh terhadap harga saham pada Perusahaan Real Estate dan Property?

4. Apakah Earning Per Share, Dividend Per Share dan Return On Investment secara bersamasama berpengaruh terhadap harga saham pada perusahaan Real Estate dan Property?

\section{LANDASAN TEORI DAN}

\section{PENGEMBANGAN HIPOTESIS}

\section{Teori Signal}

Teori Signal menjelaskan tentang bagaimana para investor memiliki informasi yang sama tentang prospek perusahaan sebagai manajer perusahaan ini disebut informasi asimetris. Namum dalam kenyataannya manajer sering memiliki informasi lebih baik dari investor luar. Hal ini disebut informasi asimetris, dan ini memiliki dampak penting pada struktur modal yang optimal (Brigham, 2005). Signaling theory juga menjelaskan mengapa perusahaan mempunyai dorongan untuk memberikan infomasi laporan keuangan pada pihak internal. Dorongan perusahaan untuk memberikan informasi tersebut adalah karena terdapat asimetri informasi antara perusahaan dan pihak investor karena perusahaan mengetahui lebih banyak mengenai perusahaan dan prospek yang akan datang dibanding pihak luar atau investor dan kreditor (Simanungkalit, 2009).

\section{Harga Saham}

Menurut Tandelilin (2001), saham merupakan surat bukti bahwa kepemilikan atas aset-aset perusahaan yang menerbitkan saham. Dengan memiliki saham suatu perusahaan, maka investor akan mempunyai hak terhadap pendapatan dan kekayaan perusahaan, setelah dikurangi dengan pembayaran semua kewajiban perusahaan. Harga saham dapat dikatakan sebagai indikator nilai perusahaan, yang dalam pandangan investor akan mencerminkan tingkat keberhasilan dari pengelolaan perusahaan atau kinerja perusahaan.

Faktor-Faktor yang Mempengaruhi Harga Saham

Faktor-faktor yang memperngaruhi harga saham adalah Earning Pershare, Return On Investment, Dividend Pershare. Penjelasannya adalah sebagai berikut : (Samsul, 2006)

\section{Earning Per Share ( EPS )}

Earning Per Share merupakan salah satu komponen yang di perhatikan dalam analisis perusahaan. Informasi EPS suatu perusahaan menunjukkan besarnya laba bersih perusahaan yang siap dibagikan untuk 
semua pemegang saham perusahaan. EPS merupakan rasio yang menunjukkan berapa besar keuntungan (return) yang diperoleh investor atau pemegang saham per lembar saham. Pada umumnya manajemen perusahaan, pemegang saham biasa dan calon pemegang saham sangat tertarik pada Earning Per Share (EPS), karena hal ini menggambarkan jumlah rupiah yang diperoleh untuk setiap lembar saham biasa dan menggambarkan prospek earning perusahaan di masa depan. (Dwipratama,2009)

\section{Dividend Per Share}

Dividend Per Share (DPS) merupakan total semua dividen tunai yang dibagikan dibandingkan dengan jumlah saham yang beredar (Intan, 2009). Informasi mengenai dividen per share sangat diperlukan untuk mengetahui berapa besar keuntungan setiap lembar saham yang akan diterima oleh para pemegang saham. Jika dividen per share yang diterima naik maka akan mempengaruhi harga saham di pasar modal. Karena dengan naiknya dividen per share kemungkinan besar akan menarik investor untuk membeli saham perusahaan tersebut. Dengan banyaknya saham yang dibeli maka harga saham suatu perusahaan akan naik di pasar modal (Maryati, 2012)

\section{Return on Investment (ROI)}

Return on Investment (ROI) digunakan untuk mengukur efiktivitas perusahaan di dalam menghasilkan keuntungan dengan memanfaatkan aktiva yang dimilikinya. Return on Investment (ROI) merupakan kemampuan perusahaan menghasilkan laba dari aktiva yang dipergunakan (Sartono 2008). Return on Investment (ROI) adalah salah satu bentuk dari rasio profitabilitas yang dimaksudkan dapat mengukur kemampuan perusahaan dengan keseluruhan dana yang ditanamkan dalam aktiva yang digunakan untuk operasinya perusahaan untuk menghasilkan keuntungan (Dwipratama, 2009).

\section{Pengembangan Hipotesis}

\section{Pengaruh Earning Per Share terhadap}

\section{Harga Saham}

Menurut Baridwan (2007) yang di maksut dengan Earning per share (EPS) atau laba per saham adalah jumlah pendapatan yang di peroleh dalam satu periode untuk setiap lembar saham yang beredar. Laba per lembar saham dapat memberikan informasi bagi investor untuk mengetahui perkembangan dari perusahaan, dalam penelitian yang dilakukan Wiguna dan mendari (2008) investor dalam mengambil keputusan banyak memperhatikan pertumbuhan Earning per Share menurut Tandellin (2001) informasi EPS suatu perusahaan 
menunjukan besarnya laba bersih perusahaan yang siap dibagikan bagi semua pemegang saham perusahaan.

Pemegang saham dan calon investor pada umumnya akan tertarik pada Earning Per Share (EPS), karena EPS merupakan salah satu indikator keberhasilan suatu perusahaan. Earning Per Share (EPS) merupakan rasio perbandingan antara laba bersih sebelum pajak dengan harga per lembar saham. EPS menunjukkan seberapa besar keuntungan yang diberikan kepada investor dari setiap lembar saham yang dimilikinya. Secara sederhana EPS menggambarkan jumlah uang yang diperoleh untuk setiap lembar saham.

Berdasarkan tingkat keberhasilan perusahaan tersebut, para investor akan memperhatikan pengaruhnya di masa yang akan datang dengan melihat prospek perusahaan yang baik. Pertumbuhan laba per lembar saham perusahaan akan sangat dipertimbangkan oleh para investor dalam membuat keputusan untuk berinvestasi. Apabila harga saham mencerminkan kapitalisasi dari laba yang diharapkan di masa yang akan datang, maka peningkatan laba akan meningkatkan harga saham dan total kapitalisasi pasar.

Penelitian terdahulu yang dilakukan Priatinah (2012), Amalia (2010), Amanda (2012) Syafitri (2012), dan Putra (2014) variabel EPS memiliki pengaruh positif dan signifikan terhadap harga saham.

$\mathrm{H}_{1}=$ Earning Per Share

(EPS)

berpengaruh terhadap harga saham

Pengaruh Dividend Per Share terhadap harga saham

Dividen per share (DPS) adalah dividen per lembar saham. Dividen per lembar saham merupakan keuntungan yang dibagikan kepada pemegang saham oleh perusahaan sebanding atau sesuai dengan jumlah saham yang dimiliki dan dapat berupa dividen tunai atau dividen saham, tetapi yang lebih sering dibagikan adalah dividen tunai, sebagai hal yang kurang beresiko dari pada potensi keuntungan modal. Dalam hal ini perusahaan perlu melakukan pertimbangan dalam pembagian dividen pada rapat umum pemegang saham tentang komposisi jumlah dividen yang akan dibagikan dengan jumlah laba ditahan. Menurut Brigham dan Houtson (2006) dalam hipotesis kandungan informasi (information signaling content), dividen yang diberikan dapat menimbulkan efek terhadap harga saham perusahaan karena dalam pengumuman pembagian dividen mengandung informasi yang penting bagi investor sebagai sinyal dari perusahaan mengenai prospek perusahaan di masa depan, Selain itu menurut Husnan (2001) faktor-faktor fundamental yang mempengaruhi harga 
saham seperti penjualan, pertumbuhan penjualan, biaya, kebijakan dividen dan sebagainya, pendapat tersebut dapat diartikan bahwa kebijakan dividen suatu perusahaan yaitu pembagian dividen suatu perusahaan yaitu pembagian dividen kepada pemegang saham merupakan salah satu faktor yang mempengaruhi harga saham.

Pengumuman peningkatan

Dividend Per Share merupakan signal yang positif bagi investor karena menunjukkan kondisi likuiditas perusahaan yang baik dan perusahaan mampu memenuhi kebutuhan investor berupa dividen. Namun, apabila perusahaan mengumumkan tingkat Dividend Per Share yang menurun, maka informasi ini diterima sebagai signal negatif yang menunjukkan penurunan kinerja perusahaan. Signal positif maupun negatif yang diterima oleh investor akan mepengaruhi tingkat penawaran dan permintaan saham. Signal positif yang diterima oleh investor menyebabkan permintaan atas saham tersebut menjadi tinggi sehingga harga saham meningkat, namun jika investor menerima signal negatif atas suatu informasi yang diumumkan oleh emiten maka permintaan saham akan menurun sehingga harga saham juga menurun.

Penelitian yang sebelumnya dilakukan oleh Naibaho (2010) yang hasilnya Dividend per Share berpengaruh positif dan signifikan terhadap harga saham. Dengan demikian dapat dikatakan bahwa semakin tinggi Dividend per Share akan semakin tinggi pula harga saham dan sebaliknya jika Dividend per Share yang dibagikan kepada pemegang saham semakin rendah maka harga saham juga semakin rendah.

Penelitian yang dilakukan oleh Hutami (2012), Wulandari (2012 dan Priatinah (2013) menyatakan bahwa DPS berpengaruh positif terhadap Harga saham.

$\mathrm{H}_{2}=$ Dividend Per Share berpengaruh terhadap harga saham

\section{Pengaruh Return On Investment terhadap harga saham}

Menurut Brigham dan Houston (2006) profitabilitas adalah hasil akhir dari sejumlah kebijaksanaan dan keputusan yang dilakukan oleh perusahaan dalam hal menunjukan kombinasi efek dari likuiditas manajemen aktiva, dan utang pada hasil operasi, rasio profitabilitas antara lain adalah margin laba atas penjualan, kemampuan dasar untuk menghasilkan laba, tingkat pengembalian total aktiva/investasi (Return on Investment/ROI) dan tingkat pengembalian atas ekuitas (ROE). Menurut Plewa, Jr dan Frieddlob sekilas 85 persen dari semua perusahaan menghitung ROI dari berbagai segmen 
bisnis sebagai bagian dari proses penilaian kinerja para manajer meyakini ROI karena ROI memperhatikan baik-baik besaran investasi maupun kegiatan yang menghasilkan labanya, kemampuan manajer dalam mengelola aset dalam pengaruh oleh usaha investasi yang akan menghasilkan laba bagi perusahaan mempunyai peran penting terhadap kinerja perusahaan untuk meningkatkan keuntungan, sehingga rasio ROI dapat dijadikan indikator dalam menilai kinerja perusahaan yang tercermin pada harga saham, investor turut berkepentingan terhadap tingkat ROI dalam berinvestasi karena dengan melihat rasio ROI maka akan terlihat kinerja perusahaan baik dan akan menghasilkan laba bersih yang tinggi atas penggunaan total aset perusahaan secara optimal maka dapat mempengaruhi nilai dari perusahaan

$$
\text { ROI menunjukkan kinerja }
$$

keuangan perusahaan dalam menghasilkan laba bersih dari aktiva yang digunakan untuk operasional perusahaan. Meningkatkan ROI berarti disisi lain juga meningkatkan pendapatan bersih perusahaan yang berarti nilai penjualan juga akan meningkat. Perusahaan yang nilai penjualannya meningkat, akan mendorong terjadinya peningkatan laba yang menunjukkan kinerja keuangan perusahaan dalam kondisi baik. Kondisi seperti ini akan mudah untuk menarik investor, karena para investor lebih suka berinvestasi pada perusahaan yang memiliki profitabilitas tinggi. Kinerja keuangan perusahaan dalam menghasilkan laba bersih dari aktiva yang digunakan akan berdampak pada para pemegang saham perusahaan.

ROI yang semakin meningkat menunjukkan kinerja perusahaan yang semakin baik dan para pemegang saham akan memperoleh keuntungan dari dividen yang diterima. Dengan semakin meningkatnya dividen yang diterima oleh para pemegang saham akan menjadi daya tarik tersendiri untuk tetap menanamkan sahamnya dan para calon investor untuk menanamkan sahamnya ke dalam perusahaan tersebut. Hal ini akan mendorong peningkatan harga saham yang pada akhirnya akan meningkatkan return saham yang akan diterima para investor.

Penelitian terdahulu oleh Amalis (2010) dan Putra (2014) yang menyatakan bahwa ROI berpengaruh signifikan terhadap harga saham.

$\mathrm{H}_{3}=$ Return On Investment berpengaruh terhadap harga saham.

\section{Pengaruh EPS, DPS, dan ROI terhadap}

\section{Harga Saham}

Berbagai macam alternatif kegiatan untuk melakukan investasi di Indonesia mempunyai banyak pilihan bagi seorang investor yang mempunyai kelebihan dana 
dalam menyalurkan dananya. Salah satu tempat investasi yang dapat digunakan oleh investor untuk melakukan investasinya selain di bank atau investasi yang berwujud seperti emas maupun tanah yaitu investasi di pasar modal. Bagi investor, pasar modal merupakan tempat untuk menyalurkan dananya dalam bentuk berupa saham. Investasi saham mempunyai daya tarik bagi investor karena dengan investasi berupa saham investor mempunyai harapan untuk memperoleh keuntungan berupa capital gain ataupun dividen saham yang tinggi. Pasar modal dapat digunakan olehinvestor untuk memperoleh tingkat penghasilan yang tinggi dan juga memiliki risiko yang tinggi terhadap investasi tersebut. Sedangkan bagi perusahaan yang go public, pasar modal merupakan tempat untuk memperoleh tambahan dana untuk kegiatan operasional perusahaan agar kelangsungan hidup perusahaan dapat bertahan dan agar dapat mampu bersaing dengan perusahaan lain.

\section{METODE}

\section{Populasi dan Sampel}

$$
\text { Populasi adalah wilayah }
$$

generalisasi yang terdiri atas obyek atau subyek yang mempunyai kualitas dan karakteristik tertentu yang ditetapkan peneliti untuk dipelajari kemudian ditarik kesimpulannya (Sugiyono,2010). Populasi dalam penelitian ini adalah perusahaan Real Estate and Property yang terdaftar di Bursa Efek Indonesia pada tahun 2012 hingga tahun 2014.

Sampel adalah bagian dari jumlah dan karakteristik yang dimiliki oleh populasi tersebut yang ingin diteliti (Sugiyono, 2010). Purposive sampling adalah pengambilan sampel dari populasi secara sengaja berdasarkan penilaian atau kriteria tertentu. Kriteria sampel dalam penelitian ini adalah sebagai berikut :

1. Perusahaan Real Estate and Property yang terdaftar di Bursa Efek Indonesia selama periode 2012-2014 secara berturut-turut.

2. Perusahaan Real Estate and Property yang mempublikasikan laporan keuangan periode 20122014

3. Perusahaan yang menyediakan data sesuai dengan variabel penelitian.

\section{Variabel Penelitian dan Definisi}

Operasional dan Pengukuran Variabel

\section{Variabel Penelitian}

Dalam penelitian ini digunakan dua variabel, yaitu sebagai berikut:

1. Variabel Terikat (Variabel Dependen).

Menurut Ferdinand

Variabel dependen adalah variabel yang menjadi pusat perhatian 
peneliti. Variabel dependen dalam

simbol sering menggunakan huruf

Y. Dalam Penelitian ini, peneliti menggunakan variabel dependen berupa harga saham.

2. Variabel Bebas (Variabel Independen).

Menurut Ferdinand (2011) variabel independen adalah variabel yang mempengaruhi variabel dipenden, baik yang pengaruhnya positif maupun yang pengaruhnya negatif. Dalam penelitian ini ada 3 (empat) variabel bebas yang digunakan, yaitu Earning Per Share (EPS), Dividend Per Share (DPS) dan Return On Investment (ROI)

\section{Definisi Operasional Variabel}

Adapun definisi variabel dalam penelitian ini adalah sebagai berikut :

1. Earning Per Share merupakan salah satu komponen yang diperhatikan dalam analisis perusahaan. Informasi EPS suatu perusahaan menunjukkan besarnya laba bersih perusahaan yang siap dibagikan untuk semua pemegang saham perusahaan. Adapun rumus yag digunakan adalah sebagai berikut

( Hutami, 2012)

Earning Per Share

$=\frac{\text { Earnings Available For Common Stockholders }}{\text { Number shares of Common Stock Outstanding }}$
2. Dividend Per Share merupakan total semua dividen tunai yang dibagikan dibandingkan dengan jumlah saham yang beredar (Intan, 2009)..

Dividen Per Share= Deviden tunai

\section{Jumlah Saham Beredar}

3. Return On Invesment adalah satu bentuk dari rasio profitabilitas yang dimaksudkan untuk dapat mengukur kemampuan perusahaan dengan keseluruhan dana yang ditanamkan dalam aktiva yang digunakan untuk operasinya perusahaan untuk menghasilkan keuntungan. Menurut Abdullah Faisal (2002) ROI ini sering disebut Return On Invesment dipergunakan untuk mengukur kemampuan perusahaan dalam menghasilkan keuntungan dengan menggunakan keseluruhan aktiva yang dimilikinya. ( Prastowo dan Juliaty 2002).

\section{Return On Invesment}

$=\underline{\text { Laba Bersih }}$

Total Aset

4. Harga saham adalah tingkat keuntungan yang dinikmati oleh pemodal atas suatu investasi saham yang dilakukannya. Rumus yang digunakan adalah 
menggunakan closing price : diterbitkan oleh perusahaan tersebut akan

Hardiningsih dkk, 2002

Harga saham $=$ closing price

\section{Kerangka Pemikiran}

Dari gambaran landasan teori dan penelitian terdahulu diperoleh suatu kesimpulan bahwa laporan keuangan memberikan gambaran kinerja perusahaan, jika laporan tersebut merefleksikan prospek perusahaan kuat dan baik, maka nilai saham yang mendapat pengaruh dan harganya akan meningkat, akan sebaliknya jika laporan tersebut merefleksikan kondisi perusahaan yang lemah dan tidak baik, maka nilai saham yang diterbitkan oleh perusahaan tersebut akan terpengaruh dan harganya akan menurun.

Berdasarkan uraian diatas maka dapat digambarkan model penelitian sebagai berikut :

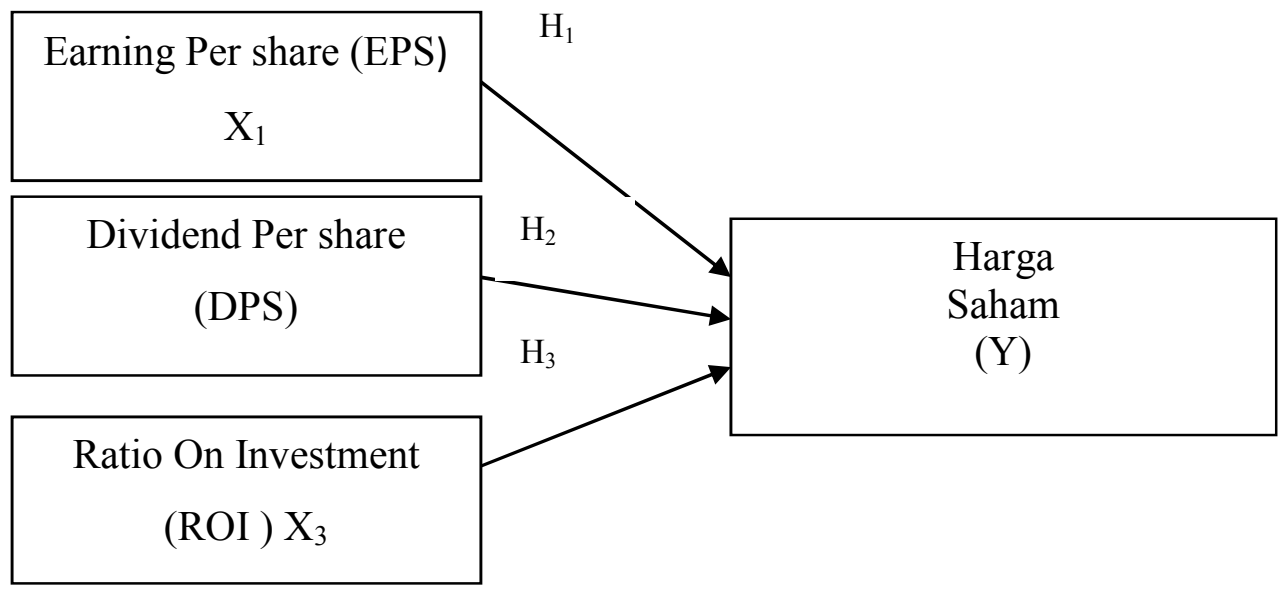

Gambar 1. Model Penelitian

\section{Regresi Linier Berganda}

Regresi linier berganda yaitu suatu model linier regresi yang variabel dependennya merupakan fungsi linier dari beberapa variabel bebas. Regresi linier berganda sangat bermanfaat untuk meneliti pengaruh beberapa variabel yang berkorelasi dengan variabel yang diuji. Teknik analisis ini sangat dibutuhkan dalam berbagai pengambilan keputusan baik dalam perumusan kebijakan manajemen maupun dalam telaah ilmiah. Hubungan fungsi antara satu variabel dependen dengan lebih dari satu variabel independen dapat dilakukan dengan analisis regresi linier berganda, dimana harga saham sebagai variabel dependen sedangkan EPS, ROI dan DPS sebagai variabel independen.

Seberapa besar variabel independen mempengaruhi variabel dependen 
dihitung dengan persamaan regresi $\mathrm{e}=$ error term

berganda sebagai berikut :

$\mathrm{Y}=\mathrm{a}+\mathrm{bX} \mathrm{X}_{1}+\mathrm{bX}_{2}+\mathrm{bX} \mathrm{X}_{3}+\mathrm{e}$

\section{HASIL DAN PEMBAHASAN}

Keterangan :

$$
\begin{array}{ll}
\mathrm{Y} & =\text { Harga saham } \\
\mathrm{A} & =\text { Konstanta } \\
\mathrm{B} & =\text { koefisien regresi berganda } \\
\mathrm{X}_{1} & =\text { EPS } \\
\mathrm{X}_{2} & =\text { DPS } \\
\mathrm{X}_{3} & =\text { ROI }
\end{array}
$$

\section{Analisis Regresi Berganda}

Hasil analisis regresi adalah berupa koefisien untuk masing-masing variabel independen. Koefisien ini diperoleh

\begin{tabular}{|c|c|c|c|c|c|c|c|c|}
\hline \multirow{2}{*}{\multicolumn{2}{|c|}{ Model }} & \multicolumn{2}{|c|}{$\begin{array}{l}\text { Unstandardized } \\
\text { Coefficients }\end{array}$} & \multirow{2}{*}{$\begin{array}{c}\text { Standardized } \\
\text { Coefficients } \\
\text { Beta }\end{array}$} & \multirow[b]{2}{*}{$t$} & \multirow[b]{2}{*}{ Sig. } & \multicolumn{2}{|c|}{ Collinearity Statistics } \\
\hline & & B & Std. Error & & & & Tolerance & VIF \\
\hline & (Constant) & 6.073 & .117 & & 51.904 & .000 & & \\
\hline & EPS & .004 & .001 & .685 & 7.553 & .000 & .934 & 1.071 \\
\hline & DPS & .007 & .003 & .196 & 2.061 & .044 & .849 & 1.178 \\
\hline & ROI & -.001 & .001 & -.058 & -.625 & .535 & .899 & 1.112 \\
\hline
\end{tabular}
dengan cara memprediksi nilai variabel dependen dengan suatu persamaan (Ghozali, 2011)

Tabel 1. Hasil uji regresi berganda

Coefficients $^{a}$

a. Dependent Variable: In_saham

Sumber : Hasil Output SPSS halaman 74

Berdasarkan tabel 1 maka dapat disusun persamaan regresi untuk mengetahui faktor-faktor fundamental dalam harga saham sebagai berikut :

$Y=6,073+0.004 X_{1}+0,007 X_{2}-0,001 X_{3+e}$

Dari persamaan tersebut diatas dapat dijelaskan :

1. Dalam koefisien regresi diatas, konstanta $\left(b_{o}\right)$ adalah sebesar 6,073 hal ini berarti jika tidak ada perubahan EPS, DPS dan ROI maka nilai harga saham adalah konstan.

2. Nilai koefisien regresi EPS diperoleh sebesar 0,004 . hal ini berarti bahwa apabila EPS naik 1\% maka akan meningkatkan harga saham sebesar $0,004 \%$.

3. Nilai koefisien regresi DPS diperoleh sebesar 0,007. hal ini berarti bahwa apabila EPS naik 1\% maka akan meningkatkan harga saham sebesar $0,007 \%$.

4. Nilai koefisien regresi ROI diperoleh sebesar 0,001. hal ini berarti bahwa apabila EPS naik 1\% maka akan menurunkan harga saham sebesar $0,001 \%$.

\section{Uji Hipotesis}

Uji F 
Untuk menguji secara simultan dilakukan analisis masing-masing koefisien regresi. Hasil analisis regresi berganda simultan dapat dilihat sebagai berikut:

Tabel 2. Hasil Uji Simultan (Uji F)

ANOVA

\begin{tabular}{|c|c|c|c|c|c|c|}
\hline Model & & $\begin{array}{l}\text { Sum of } \\
\text { Squares }\end{array}$ & df & Mean Square & $\mathrm{F}$ & Sig. \\
\hline \multirow[t]{3}{*}{1} & Regression & 29.103 & 3 & 9.701 & 24.716 & $.000^{\mathrm{a}}$ \\
\hline & Residual & 21.980 & 56 & .392 & & \\
\hline & Total & 51.083 & 59 & & & \\
\hline
\end{tabular}

a. Predictors: (Constant), ROI, EPS, DPS

b. Dependent Variable: In_saham

Sumber : Data sekunder yang diolah, 2015

Nilai signifikan dalam penelitian ini adalah 0,000 yaitu $<0,05$ maka keputusan dalam penelitian ini adalah model dapat diterima. Hal ini menunjukkan bahwa secara simultan terdapat pengaruh EPS,DPSdan ROI terhadap harga saham pada perusahaan real estate dan property yang terdaftar di Bursa Efek Indonesia tahun 2012-2014.

\section{Uji Signifikan Parameter Individual (Uji t)}

Uji t menunjukkan seberapa jauh pengaruh satu variabel penjelas atau independen secara individual dalam menerangkan variasi variabel independen.

Tabel 3. Uji Signifikansi Parameter individual ( Uji t)

\begin{tabular}{|c|c|c|c|c|c|c|c|c|}
\hline \multicolumn{9}{|c|}{ Coefficients $^{a}$} \\
\hline \multirow{2}{*}{\multicolumn{2}{|c|}{ Model }} & \multicolumn{2}{|c|}{$\begin{array}{c}\text { Unstandardized } \\
\text { Coefficients }\end{array}$} & \multirow{2}{*}{$\begin{array}{c}\text { Standardized } \\
\text { Coefficients } \\
\text { Beta } \\
\end{array}$} & \multirow[b]{2}{*}{$\mathrm{t}$} & \multirow[b]{2}{*}{ Sig. } & \multicolumn{2}{|c|}{ Collinearity Statistics } \\
\hline & & $\mathrm{B}$ & Std. Error & & & & Tolerance & VIF \\
\hline 1 & (Constant) & 6.073 & .117 & & 51.904 & .000 & & \\
\hline & EPS & .004 & .001 & .685 & 7.553 & .000 & .934 & 1.071 \\
\hline & DPS & .007 & .003 & .196 & 2.061 & .044 & .849 & 1.178 \\
\hline & ROI & -.001 & .001 & -.058 & -.625 & .535 & .899 & 1.112 \\
\hline
\end{tabular}

a. Dependent Variable: In_saham

Sumber : Hasil Output SPSS

1. Hipotesis 1 : EPS berpengaruh terhadap harga saham Variabel EPSmemiliki nilai signifikasi $0,000<(0,05)$ artinya variable EPS berpengaruh terhadap harga saham . Dengan demikian $\mathbf{H 1}$ diterima

2. Hipotesis 2 : DPS berpengaruh terhadap harga saham 
Variabel DPS memiliki nilai $\mathrm{t}$

hitung dengan nilai probabilitas

$0,044<(0,05)$ artinya variable

DPS berpengaruh terhadap

harga saham. Dengan demikian

\section{H2 diterima}

3. Hipotesis 3 : ROI tidak berpengaruh terhadap harga saham

Variabel ROI memiliki nilai $\mathrm{t}$ hitung dengan nilai signifikasi $0,535>(0,05)$ artinya variabel
ROI tidak berpengaruh terhadap harga saham. Dengan demikian

\section{H3 ditolak}

\section{Uji Koefisien Determinasi $\left(\mathbf{R}^{\mathbf{2}}\right)$}

Uji koefisien Determinan $\left(\mathrm{R}^{2}\right)$ Pada intinya untuk mengukur seberapa jauh kemampuan model dalam menerangkan variasi variabel dependen. Dengan melihat Adjusted $R$ Square maka dapat diketahui prosentase pengaruh semua variabel independen terhadap variabel dependen (Ghozali, 2011).

Tabel 4. Hasil Uji Koefisien Determinan $\left(\mathrm{R}^{2}\right)$

Model Summary ${ }^{b}$

\begin{tabular}{|l|r|r|r|r|c|}
\hline Model & R & R Square & $\begin{array}{c}\text { Adjusted } \\
\text { R Square }\end{array}$ & $\begin{array}{c}\text { Std. Error of } \\
\text { the Estimate }\end{array}$ & $\begin{array}{c}\text { Durbin- } \\
\text { Watson }\end{array}$ \\
\hline 1 & $.755^{\mathrm{a}}$ & .570 & .547 & .62650 & 1.848 \\
\hline
\end{tabular}

a. Predictors: (Constant), ROI, EPS, DPS

b. Dependent Variable: In_saham

Sumber : Hasil Output

Berdasarkan table 4.9, nilai adjusted $\mathrm{R}$ square sebesar $0,547 \quad \%$ variabel dependen dijelaskan oleh keenam variabel independen, sedangkan sisanya sebesar 45,3 \% (100-54,7\%) dijelaskan oleh variabel independen lain yang tidak dimasukkan ke dalam model.

\section{Hasil Penelitian dan Pembahasan}

Pengaruh EPS terhadap Harga

\section{Saham}

Earning Per Share (EPS) adalah perbandingan antara laba bersih dengan pendapatan operasional. Hasil dari uji-t diketahui bahwa EPS terhadap harga saham memiliki pengaruh yang signifikan dan hubungan positif. Saat laba bersih naik dan jumlah lembar biasa turun maka EPS akan naik itu berarti semakin besar EPS semakin tinggi kemampuan perusahaan untuk mendistribusikan pendapatan kepada pemegang sahamnya, mencerminkan semakin besar keberhasilan usaha yang dilakukannya sehingga pengembalian yang akan diterima investor semakin tinggi dan investor akan tertarik untuk membeli 
saham tersebut dan hal itu menyebabkan harga pasar saham cenderung naik

Hal tersebut dapat dicontohkan dari data penelitian pada tahun 2013 pada perusahaan Jakarta International Hotel dan Development Tbk memiliki nilai Earning Per Share (EPS) sebesar 758 (diatas rata Earning Per Share (EPS)) sebesar 132,7462 dan harga saham seebsar 1.477,265. Dan pada tahun 2013 perusahaan Dadanayasa Arthatama Tbk memiliki nilai Earning Per Share (EPS) sebesar 528 (diatas rata Earning Per Share (EPS)) sebesar 132,7462 dan harga saham sebesar 1.477,265

Widoatmodjo dalam Priatinah (2012) menyatakan bahwa EPS dapat digunakan untuk menilai baik atau tidaknya kinerja perusahaan, sehingga semakin tinggi EPS akan semakin mahal suatu saham. Hal tersebut didukung oleh Syamsuddin (2011) dalam Priatinah (2012) bahwa investor tertarik dengan nilai EPS yang besar, sehingga meningkatnya nilai EPS akan meningkatkan harga saham. Hasil analisis tersebut diperkuat oleh penelitian terdahulu yang dilakukan Yerrika (2009) dalam Priatinah (2012) dimana secara parsial variabel EPS memiliki pengaruh positif dan signifikan terhadap harga saham.

Dalam penelitian ini EPS berpengaruh cukup besar terhadap harga saham, sehingga EPS dapat digunakan sebagai salah satu rasio pertimbangan dalam menginvestasikan dana bagi investor.

\section{Pengaruh DPS terhadap Harga Saham}

Dividend per Share merupakan total semua dividen tunai yang dibagikan kepada pemegang saham dibandingkan dengan jumlah saham yang beredar. Dividend per Share digunakan untuk mengukur berapa rupiah yang diberikan kepada pemegang saham dari laba bersih perusahaan untuk setiap lembar saham. Salah satu alasan investor membeli saham adalah untuk mendapatkan dividen (Gibson, 2003). Selain itu, menurut Sutrisno (2003) investor mengharapkan dividen yang diterimanya dalam jumlah besar dan mengalami peningkatan setiap periode. DPS yang tinggi mencerminkan perusahaan memiliki prospek yang baik dan akan menarik investor yang memanfaatkan dividen untuk keperluan konsumsi. Apabila DPS yang diterima naik tentu saja hal ini akan menarik investor untuk membeli saham perusahaan tersebut. Dengan banyaknya saham yang dibeli maka harga saham perusahaan tersebut akan naik di pasar modal. Serta menurut Teori Signaling Hyphotesis yaitu teori yang diungkapkan oleh Rozeff (1982) yang beranggapan bahwa dividen tampaknya memiliki informasi atau sebagai isyarat akan prospek perusahaan. 
Apabila perusahaan meningkatkan pembayaran dividen, mungkin diartikan oleh pemodal sebagaisinyal harapan manajemen tentang akan membaiknyakinerja perusahaan di masa yang akan datang. Hal tersebut dapat dicontohkan dari data penelitian pada tahun 2012 pada perusahaan Metropolitan Kentjana Tbkmemiliki nilai Dividen Per Share (DPS) sebesar 165,000 (diatas ratarata Dividend per Share) sebesar 18,38564 dan harga saham seebsar 1.477,265. Dan pada tahun 2013 perusahaan Intiland Development Tbk memiliki nilai Dividend per Share sebesar 78,275 (diatas rata Dividend per Share sebesar 18,38564) dan harga saham sebesar $1.477,265$

$$
\text { Bhatta charya }
$$
mengembangkan suatu model sinyal (signal model), bahwa tingginya dividen yang dibagikan menunjukkan tingginya performance perusahaan yang nantinya akan meningkatkan nilai perusahaan dan harga saham perusahaan tersebut.

Selain itu, hasil penelitian ini sejalan dengan penelitian yang sebelumnya dilakukan oleh Cerpen Naibaho (2010) yang hasilnyaDividend per Share berpengaruh dan signifikan terhadap harga saham. Dengan demikian dapat dikatakan bahwa semakin tinggi Dividend per Share akan semakin tinggi pula harga saham dan sebaliknya jika
Dividend per Share yang dibagikan kepada pemegang saham semakin rendah maka harga saham juga semakin rendah.

\section{Pengaruh ROI terhadap harga Saham}

Hasil penelitian mengenai pengaruh ROI terhadap harga saham ini ternyata tidak berpengaruh signifikan terhadap harga saham. Diperoleh nilait hitung sebesar -2,217 lebih besar dari t tabel 2,048 dan taraf signifikansi lebih kecil0,05 yaitu 0,029.Dengan demikian H0 di terima dan Ha ditolak, maka hipotesis 2 menyatakan ROI tidak berpengaruh terhadap harga saham diterima.

Hasil penelitian ini sesuai dengan signal theory dimana investor akan merespon informasi positif ataupun negatif dari perusahaan. ROI dalam penelitian ini ternyata tidak memberikan pengaruh terhadap harga saham, ini artinya ROI bukan merupakan informasi yang positif bagi investor untuk menjual atau membeli saham sehingga berpengaruh terhadap harga saham.

Hal ini disebabkan karena pasar atau pasar investor tidak mengapresiasikan atas kenaikan ROI, karena laba yang diperoleh dari kenaikan ROI cenderung tidak dibagikan dalam deviden namun digunakan untuk aktivitas pengelolaan asset perusahaan dan pembayaran hutang Putra (2014). 
Hasil penelitian sejalan dengan penlitian terdahulu oleh Priatinah dan Kusuma (2012) yang menyatakan bahwa ROI berpengaruh signifikan terhadap harga saham secara parsial sedangkan hasil penelitian ini tidak sejalan dengan penelitian yang dilakukan oleh Mehrini (2012) yang menyatakan ROI tidak berpengaruh terhadap harga saham.

\section{Pengaruh EPS, DPS dan ROI trhadap}

\section{Harga Saham}

Hasil penelitian ini menunjukkan bahwa Return on Investment, Earning per Share dan Dividen per Share secara simultan berpengaruh positif terhadap Harga Saham. Nilai $\mathrm{R}$ positif sebesar 0,917 artinya Return on Investment, Earning per Share dan Dividen per Share secara bersama-sama (simultan) berpengaruh positif terhadap Harga Saham. Koefisien determinasi (R2) sebesar 0,841 artinya menunjukkan bahwa $84,1 \%$ varians yang terjadi pada Harga Saham ditentukan oleh variable Return on Investment, Earning per Share dan Dividen per Share, sedangkan 15,9\% dipengaruhi oleh variabel lain yang tidak diteliti.

\section{PENUTUP}

Berdasarkan hasil analisis regresi yang dilakukan terhadap variabelvariabel yang mempengaruhi harga saham pada
Perusahaan Real estate dan Property yang terdaftar di Bursa Efek Indonesia periode tahun 2012-2014 maka dapat disimpulkan sebagai berikut :

1. Variabel EPS berpengaruh terhadap harga saham pada Perusahaan Real Estate dan Property di Bursa Efek Indonesia.

2. Variabel DPS berpengaruh terhadap harga saham pada Perusahaan Real Estate dan Property di Bursa Efek Indonesia.

3. Variabel ROI tidak berpengaruh terhadap harga saham pada perusahaan Real Estate dan Property di Bursa Efek Indonesia.

4. EPS, DPS dan ROI secara simultan berpengaruh terhadap harga saham pada Perusahaan Real Estate dan Property di Bursa Efek Indonesia.

\section{Keterbatasan Penelitian}

1. Pada penelitian ini, peneliti hanya memperhitungkan aspek fundamental perusahaan sebagai bahan pertimbangan investasi melalui sekuritas, karena itulah, pada penelitian selanjutnya, variabel kontrol seperti inflasi, tingkat suku bunga, dan faktor politik dapat dimasukkan sebagai variabel untuk diteliti, sehingga mampu menambah informasi yang berguna untuk 
keputusan investasi di pasar modal saham.

2. Setelah diketahui keterbatasan penelitian diatas maka agenda penelitian yang akan datang adalah melakukan penelitian tidak hanya pada perusahaanReal Estate dan property saja tetapi juga pada perusahaan lain-lain. selain itu variable bebas yang digunakan menggunakan rasio yang lain seperti Grost Profit Margin (GPM), ,Dividend Payout Ratio (DPR) dan rasio keuangan lainnya serta faktor makro seperti inflasi, tingkat suku bunga, pertumbuhan ekonomi Indonesia, kurs valuta asing maupun harga minyak dunia. Serta periode peneltian bias ditambah menjadi lima tahun.

\section{SARAN}

Berdasarkan hasil penelitian dan kesimpulan, saran yang dapat diberikan sebagai berikut :

1. Hasil penelitian ini diharapkan mampu memberikan beberapa kontribusi penting, khususnya bagi investor dalam menentukan keputusan investasinya di pasar modal, dengan memanfaatkan laporan arus kas dan laba akuntansi, di sisi lain untuk menilai sekuritas juga mempertimbangkan dan menganalisis lingkungan ekonomi dan industri selama proses penilaian berlangsung hal ini berpengaruh besar dalam perusahaan.

2. Dalam melakukan investasi pada perusahaan real estate dan property yang pertama diperhatikan seorang investor adalah variabel ROI karena memiliki pengaruh terbesar dalam mengambil keputusan investasinya.

3. Bagi perusahaan penelitian yaitu perusahaan real estate dan property yang go - public perlu mempertimbangkan variabel ROI dalam pengembangan perusahaan.

\section{DAFTAR PUSTAKA}

Abid Dzajuli. 2006. “ Pengaruh EPS, ROI, dan ROE Terhadap Harga Saham Pada Perusahaan Sektor Manufaktur Pada Bursa Efek Jakarta (BEJ). Fordema. Volume 6. Nomor 1:51 - 62 .

Agus Harjito dan Martono, Manajemen Keuangan. Edisi Kedua, Cetakan Pertama, Penerbit EKONISIA, Yogyakarta, 2011.

Amanda, Astrid dan Darmanto, Ahmad Husaini. 2011. Pengaruh Debt Equity Ratio, Return On Equity, Earning Per Share dan Price Earning Ratio terhadap Harga Saham. Studi Pada Perusahaan Food and Beverage yang terdaftar 
di BEI tahun 2008-2011. Jurnal Bisnis dan Ekonomi. Vol. 4 No. 2.

Anastasia, Njo. 2001. Analisis Faktor Fundamental dan Risiko Sistematik Terhadap Harga Saham Properti di BEJ, Jurnal Akuntansi dan Keuangan, Universitas Kristen Petra Vol.5 No.2: 123-131.

Anastasia, S. Mendari dan Robin Wiguna dan. 2008. " Pengaruh Earning Per Share dan tingkat suku bunga SBI terhadap harga saham Pada Perusahaan Yang Terdaftar Di LQ45 BEI”. Jurnal Keuangan Dan BIsnis. Vol 6. No.2 Hal.130142 .

Ang, Robbert .1997, Buku Pintar: Pasar Modal Indonesia. Mediasoft Indonesia. Halim, Abdul, 2005, Analisis Investasi. Edisi Kedua. Jakarta : Salemba Empat.

Arifin, Ali. 2004. Membaca Saham. Yogyakarta : Andi.

Arista, Desy dan Astohar. (2012). Analisis Faktor-faktor yang Mempengaruhi Return Saham (Kasus pada Perusahaan Manufaktur yang Go Public di BEI periode tahun 20062009. Jurnal Ilmu Manajemen dan Akuntansi Terapan,3(1), 115.

Astrid Amanda dkk. 2011. Pengaruh Debt Equity Ratio, Return On Equity, Earning Per Share dan Price Earning Ratio terhadap Harga Saham. Studi Pada Perusahaan Food and Beverage yang terdaftar di BEI tahun 2008-2011. Jurnal Bisnis dan Ekonomi. Vol. 4 No. 2.

Bodie, et al, 2003. Essential of Investments, International Edition, McGrawn-Hill, New York.
Brealy, Myers dan Marcus. 2007. DasarDasar Manjemen Keuangan Perusahaan. Edisi Kelima. Jakarta: Erlangga.

Brigham, Eugene $\mathrm{F}$ dan Joel F. Houston.2006. Manajemen Keuangan. Jakarta: Erlangga.

Darmadji, Tjiptono dan Hendi M. Fakhruddin. 2006. Pasar Modal Di Indonesia: , Pendekatan Tanya Jawab. Edisi Kedua. Jakarta: Salemba Empat.

Denies Priatinah Prabandaru Adhe Kusuma. 2012. Pengaruh Return On Investment (ROI), Earning Per Share (EPS), Dan Dividen Per Share (DPS) Terhadap Harga Saham Perusahaan Pertambangan Yang Terdaftar Di Bursa Efek Indonesia (BEI) Periode 20082010. Jurnal Nominal/Volume 1Nomor 1/ Tahun 2002.

Devi N. L. P. A. C. D. dan Sudjiarni L. K. 2012. Pengaruh Kinerja Keuangan terhadap Pendapatan Saham dengan DPR sebagai Variabel Moderasi di BEI. Jurnal Manajemen, 1(1): 110.

Ferdinand, Augusty. 2011. Metode Penelitian Manajemen. Edisi Ketiga. Semarang. Badan Penerbit UNDIP.

Franklin Plewa,Jr dan George T. Friedlob. 1993. Seri Bisnis Barron: Laba Investasi (ROI) dan Perencanaan Keuangan. Jakarta: PT Elex Media Komputindo.

Gede Priana Dwipratama. 2009. Pengaruh $P B V, D E R, E P S, D P R$ dan ROA Terhadap Harga Saham(Studi Empiris pada Perusahaan Food and Beverage yang Terdaftar di Bursa Efek Indonesia), Universitas Gunadarma, Depok. 
Ghozali, Imam. 2013. Aplikasi Analisis Multivariate dengan Program SPSS19. Edisi Kelima.Semarang: BP Universitas Diponegoro.

Hanafi, Mamduh M. 2010. Manajemen Keuangan. Edisi Pertama. Yogyakarta: BPFE Yogyakarta.

Hardiningsih,

Pancawati, 2002, "Pengaruh Faktor Fundamental Dan ResikoEkonomi Terhadap Return Saham Pada Perusahaan Di Bursa Efek Jakarta: Studi Kasus Basic Industry \& Chemical", Jurnal Strategi Bisnis, Vol. 8, Des.

Harkivent dan Murtanto. 2001. Analisis Hubungan Harga saham dengan Komponen-Komponen Laporan Keuangan Perusahaan Asuransi Kerugian yang diuraikan dengan Rasio Early Warning System.Jurnal Bisnis dan Akuntansi. Volume 3. No. 2 Agustus,457-476.

Heny, Mehrani. 2011. Pengaruh Return In Investmen (ROI), Earning Pershare (EPS) dan Price

Earning Ratio (PER) terhadap Harga Saham Pada PT Indofood Sukses Makmur Tbk. Dinamika Keuangan dan Perbankan, Mei Vol.3 No. 1.

Henny Septiana Amalia. 2010. Jurnal Manajemen dan Akuntansi. Vol 11. Nomor 2. Hal.98-106.Halim, Abdul. 2005. Analisis Investasi. Edisi Kedua. Salemba Empat. Jakarta.

Husnan, Suad dan Enny Pudjiastuti. 2006. Dasar-Dasar Manajemen Keuangan, edisi kelima.Yogyakarta: UPP STIM YKPN.
Hutami, Resciyana Putri. 2012. Pengaruh Dividen Per Share (DPS) Return On Equity (ROE), Dan Net Profit Margin (NPM) Terhadap Harga Saham Perusahaan Industri Manufactur Yang Tercatat Di Bursa Efek Indonesia (BEI) Periode 20062010. Jurnal Nominal/Volume 1Nomor 1 / Tahun 2012.

Jama'an. 2008. Signaling Theory. Diambil dari: http://ekonomi.kabo.biz/201 1/07/teori-sinyal.html) dikases tanggal 20 maret 2014.

Jogiyanto. 2000. Teori Portofolio dan Analisis Investasi. Edisi Ketiga. Yogyakarta: BPFE.

Kasmir, 2004. Bank dan Lembaga Keuangan Lainnya. Jakarta : PT. Raja Grafindo Persada

Ni Putu Nova Eka Yanti dan I Ketut Suryanawa. pengaruh earnings per share terhadap harga saham dengan dividend per share sebagai variabel moderasi. e-jurnal akuntansi universitas udayana 3.2 (2013): 212-228.

Noer Sasongko dan Nila Wulandari 2012. Pengaruh Eva Dan RasioRasio Profitabilitas Terhadap Harga Saham Empirika, Vol.19 No.1, Juni 2006: 64-80.

Maria Immaculatta. 2006. Signaling Theory. Diambil dari: http://ekonomi.kabo.biz/201 1/07/teori-sinyal.html) dikases tanggal 20 maret 2014.

Marwata, Kinerja Keuangan, Harga Saham dan Pemecahan Saham. Jurnal Riset Akuntansi Indonesia, Vol. 6, No. 3, P. 264-275.

Mehrani dan Safitri, Heny,. 2011. Pengaruh Return In Investmen 
(ROI), Earning Pershare (EPS) dan Price Earning Ratio (PER) terhadap Harga Saham Pada PT Indofood Sukses Makmur Tbk. Dinamika Keuangan dan Perbankan, Mei Vol.3 No. 1.

Minar Simanungkalit, 2009. “ Pengaruh Profitabilitas da Leverage Keuangan terhadap Return Saham". Skripsi. Undip, Semarang.

Prastowo, Dwi, dan Rifka Juliaty. 2002. Analisis Laporan Keuangan Konsep dan Aplikasi. Yogyakarta :UPP STIM YKPN.

Priatinah Prabandaru, Denies dan Adhe Kusuma. 2012. Pengaruh Return On Investment (ROI), Earning Per Share (EPS), Dan Dividen Per Share (DPS) Terhadap Harga Saham Perusahaan Pertambangan Yang Terdaftar Di Bursa Efek Indonesia (BEI) Periode 2008-2010. Jurnal Nominal/Volume 1Nomor 1/ Tahun 2002.

Putra. Yoga Pratama 2014. Pengaruh Return On Investment (ROI) ,Return On Equity (ROE), Net Profit Margin (NPM) Dan Earning Per Share Terhadap Harga Saham (Studi Pada Perusahaan Properti Dan Real Estate Yang Tercatat Di Bursa Efek Indonesia (BEI) Periode 2010-2012. Jurnal Administrasi Bisnis $(J A B)$ /Volume 8 Nomor 2 /Maret 2014.

Resciyana Putri Hutami. 2012. Pengaruh Dividen Per Share (DPS) Return On Equity (ROE), Dan Net Profit Margin (NPM) Terhadap Harga Saham Perusahaan Industri Manufactur Yang Tercatat Di Bursa Efek Indonesia (BEI) Periode 2006-2010. Jurnal
Nominal /Volume 1Nomor 1 / Tahun 2012.

Robin Wiguna dan Anastasia S. Mendari. 2008. " Pengaruh Earning Per Share dan tingkat suku bunga SBI terhadap harga saham Pada Perusahaan Yang Terdaftar Di LQ45 BEI". Jurnal Keuangan Dan BIsnis. Vol 6. No.2 Hal.130142.

Samsul, Mohamad, 2006. Pasar Modal dan Manajemen Portofolio. Erlangga, Jakarta.

Sartono, Agus.2001. Manajemen Keuangan Teori dan Aplikasi. Edisi Keempat. Yogyakarta: BPFE.

Sawidji, Widoatmojo. 2005. DasarDasar Manajemen Keuangan. Edisi Pertama. Jakarta: Salemba

Sugiyono. 2010. Metode Penelitian Bisnis, Penerbit CV Alfabeta, Bandung.

Susilowati, Yeye. 2006. Reaksi Signal Rasio Profitabilitas dan rasio Solvabilitas Terhadap Return Saham Perusahaan. Dinamika Keuangan dan Perbankan. Vol 3, No.1, Hal: 17-37, Mei 2011, ISSN: 1979-4878. Universitas Stikubank. Semarang.

Sunariyah. 2004. Pengantar Pengetahuan Pasar Modal. Yogyakarta: UPP AMP YKPN.

Stella. 2009. Pengaruh Price to Earnings Ratio, Debt to Equity Ratio, Return On Asset, dan Price to Book Value terhadap Harga Pasar Saham. Jurnal Bisnis dan Akuntansi, 11(2): 97-106.

Sudana, I Made. 2011. Manajemen Keuangan Perusahaan Teori dan Praktik. Jakarta: Erlangga. 
Suroto, Anita. 2012. Pengaruh Faktor Fundamental Internal terhadap Harga Saham (Studi pada Saham LQ45 yang listing di BEI

Tandelin, Eduardus. 2001. Analisis Investasi dan Mnajemen Portofolio. Edisi Pertama : BPFE.

Tita Deitiana. 2011. Pengaruh Rasio Keuangan Pertumbuhan Penjualan dan Dividen Terhadap Harga Saham. Jurnal Bisnis Dan Akutansi. Vol. 13 No. 1, April 2011: Hal. 57-66.

Weston, J.Fred dan Thomas E Copeland.2001. Manajemen Keuangan.Jakarta : Erlangga

Wulandari, Amelia Dwi. Pengaruh Earning Per Share Dan Dividend Per Share Terhadap Harga Saham (Kasus Pada Perusahaan LQ45 yang Terdaftar di Bursa Efek Indonesia) Fakultas Ekonomi Universitas Siliwangi.

Wolk, Et al. 2001. Signaling Theory. Diambil dari: http://ekonomi.kabo.biz/201 1/07/teori-sinyal.html) dikases tanggal 20 maret 2014.

www.detikfinance.com.

www.indonesiafinancetoday.com.

Yoga Pratama Putra. 2014. Pengaruh Return On Investment (ROI) ,Return On Equity (ROE), Net Profit Margin (NPM) Dan Earning Per Share Terhadap Harga Saham (Studi Pada Perusahaan Properti Dan Real Estate Yang Tercatat Di Bursa Efek Indonesia (BEI) Periode 2010-2012. Jurnal Administrasi Bisnis (JAB) /Volume 8 Nomor 2 /Maret 2014.
Yuliati, Artafya Tri. 2011. Pengaruh Variabel Earning Per Share (EPS), Price Earning Ratio (PER), Return On Equity (ROE) terhadap Harga Saham (Studi pada Perusahaan Mining periode 2008-2009).

Zuliarni, S. 2012. Pengaruh Kinerja Keuangan terhadap Harga Saham pada Perusahaan Mining dan Mining Service di Bursa Efek Indonesia. Jurnal Aplikasi Bisnis, 3(1): 36-48. 